\title{
Development of Computer-Based Kindergarten Children's Creativity Portfolio Assessment Instruments
}

\author{
Marwah Nazhifah Sitorus ${ }^{1}$, Anita Yus ${ }^{2}$, Daulat Saragi ${ }^{3}$ \\ ${ }^{1}$ Postgraduate Program in Universitas Negeri Medan, Indonesia \\ ${ }^{2,3}$ Universitas Negeri Medan, Indonesia \\ marwahnazhifahsitorus@gmail.com
}

\section{Abstract}

The problem in this study is that teachers still have difficulty assessing children's creativity, so the aim of this study is to develop a computerbased assessment instrument for the creativity portfolio of kindergarten children. This research is a Research and Development $(R \& D)$ using the ADDIE development model through 5 stages, namely: analyze, design, development, implementation and evaluation. Subjects in this study consisted of 3 teachers in Group A TK ABA 05 Medan. Then 6 validation experts who have the appropriate knowledge of this development research, among others: a) 2 assessment experts, b) 2 computer experts, c) 2 early childhood experts. The determination of the feasibilitylevel of the portfolio assessment instrument is based on the validation test of the experts, while the level of effectiveness of the portfolio assessment instrument is based on trials for teachers through teacher response questionnaires. Based on the results of the study, it was found that the assessment of the assessment expert validator I in this category was considered very valid with a percentage of $83 \%$ which means that it is very suitable for use and the second assessment expert in the category is considered very valid with a percentage of $83 \%$ which means very suitable for use. Then the computer expert I in the category is considered valid with a percentage of $81 \%$ which means it is suitable for use and the computer expert II in the category is considered very valid with a percentage of $86 \%$ which means very suitable for use. Furthermore, early childhood expert I in the very valid category with a percentage of $93 \%$ which means that it is very suitable for use and early childhood expert II in the category is considered valid with a percentage of $73 \%$ which means it is suitable for use. The results of the teacher response questionnaire on portfolio assessment using a gain score test with a value of 0.74 and can be categorized as high effectiveness, this indicates that the use of portfolio assessment instruments has been effectively used by TK ABA 05 Medan teachers.
Keywords

portfolio assessment; children's creavity

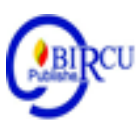

\section{Introduction}

Creativity is a very important thing for children, through a pleasant atmosphere the child will be able to create and pour out the creations, ideas or thoughts that the child has. Creativity gives children immense pleasure and satisfaction and appreciation which has a real influence on a child's development. Creative children who have different thoughts always 
take the initiative to be full of creativity and do not depend on others so that children are able to be creative.

Assessment in educational institutions is very necessary to be a tool for educators to improve the quality of education and comply with institutional administrative rules or provide information to parents about the development of their children. With the implementation of learning using the 2013 curriculum, children are expected to be able to learn in a fun, more meaningful way naturally. Because each stage in the learning process is considered in the assessment system that directs competency-based assessments or process and outcome assessments.

Assessment serves to assess the extent to which children can achieve the goals of learning, to measure the overall learning outcomes and process in various ways. One form of assessment in learning that supports this is portfolio assessment. Portfolio assessment is often likened to a photo album of an activity that records program activities and participants.

Portfolio assessment, if carried out correctly and systematically, can be a better tool for measuring practices, procedures and outputs when compared to traditional measurement tools. In addition, with a portfolio assessment, the teacher can assess children's creativity through portfolio exhibitions, children can explore the ideas they have so they can create a beautiful work. Then teachers and parents can work together in assessing children's creativity. In the era of technology and information, the use of computers is required in every learning process including assessment, Bambang and Dian (2018: 105) state that in their research results from the results of interviews and observations to several kindergarten schools in Ponorogo, the authors found almost all types of student development assessment reports. still manually written. Likewise with the results of research by Setemen et al. (2018: 55) based on the results of the survey, it is reasonable to develop a computer-based assessment system, where the system developed can accommodate the needs of teachers in the assessment process, especially related to the involvement of students in the assessment.

Through computer technology teachers can improve the quality of learning by facilitating the teacher's task in assessing what will be processed by computer programs and then obtaining results in the form of information on child development. Advances in computer technology are always developing so that the authors are interested in developing an instrument for assessing the creativity portfolio of kindergarten children.

Based on the results of observations and interviews of researchers with teachers in 2 Kindergartens in Medan regarding portfolio assessment, several problems were found, namely, the portfolio assessment had actually started at the time the Competency-Based Curriculum was issued by issuing portfolio guidelines for assessing by the Ministry of National Education, appealing to teachers and managers. education for developing portfolio assessments. However, the teacher is still unable to develop a portfolio assessment, so that the assessment of children's portfolios is still in the form of children's work collected in one stofmap which will be divided at the end of the semester.

When the teacher assesses children's creativity, they still have difficulties because the teacher is still doing manual assessments with stars so that the assessment is not accurate. In addition, the problem that occurs is the teacher is still lacking in providing information to parents about how creative the child is, because the teacher makes the assessment a little slow and reports the child's assessment at the end of each semester. Then the teacher does not have an assessment rubric on every activity carried out by the child to be able to assess how creative the child is. 
The development of the portfolio assessment referred to in this study using software that can be installed by teachers on computer devices, in this software there are several characteristics of the assessment as a strategy for developing the creativity of children aged 45 years. Then the teacher fills in and inputs the children's work by choosing a grade for the child with a rubric that has been determined according to the child's creativity development and writes down some of the teacher's notes about the child's process of learning. The software can be used for 30 children and can be printed by the teacher and then given to the parents.

Based on the description above, the authors are interested in conducting research on "Development of Computer-Based Kindergarten Children's Creativity Portfolio Assessment Instruments".

\section{Review of Literatures}

\subsection{Kindergarten Creativity}

Many definitions are revealed when talking about creativity as expressed by Mutiah (2010: 43) that creativity is a person's thinking ability to produce ideas that are smooth, flexible, detailed, new and original or produce solutions to problems that are relatively different from before. This is in line with Susanto's (2011: 112) opinion that creativity is the ability to create something new, either in the form of new products or ideas that can be applied in solving problems or as an ability to see pre-existing elements.

The opportunity to acquire knowledge, creativity does not arise in a void. The more knowledge the child acquires, the better the basics for achieving creative results. Furthermore, according to Saragi $(2014: 8)$ in his article, the role of the teacher must be a guide who helps children gains their own confidence, to then carry out their opinions and inspire their creativity without hesitation. According to Rachmawati and Kurniati (2010: 27) there are four factors that influence the development of children's creativity, namely: (1) mental stimulation, a creative work can emerge if the child gets supporting mental stimulation. (2) Environmental conditions, environmental conditions around children are very influential in fostering and developing creativity.

A conducive environment will support the development of children's creativity. (3) the role of teachers, creative teachers are teachers who are able to use various approaches in the process of learning activities and guide their students. One of the activities that teachers can do is using portfolio assessment. (2) The role of parents, accepting the strengths and weaknesses of children, will be able to help children stimulate their creativity. Thus the establishment of cooperation between children and parents is the first step in stimulating their creative power.

\subsection{Portfolio Assessment}

Portfolio assessment according to Arifah and Yustisianisa (2012: 29) is an assessment that tries to explore, collect, report, and use authenticity or authenticity of the appearance or performance of students. While Ambara, et al (2014: 112) say that portfolio assessment is a class-based assessment of a group of students who are arranged systematically and organized which is taken during the learning process within a certain period of time. Furthermore, Surapranata and Hatta (2007: 71) revealed that portfolio assessment is an alternative to improve students' abilities (student achievement) through feedback evaluation and selfassessment. 
There are various types of portfolios with various purposes and interests, generally these various types of portfolios can fulfill part or all of education and learning programs in schools. According to Sujiono (2010: 9) explains that the types of portfolio assessment include:

\section{a. Documentation Portfolio}

This type is known as a "working portfolio". This approach includes a collection of jobs over a certain period of time that shows the growth and progress of learners' learning about the learning outcomes that have been identified.

\section{b. Process Portfolio}

This approach documents all aspects of the learning process. This portfolio shows how learners engage in specific knowledge or skills, and progress towards basic and advanced mastery.

\section{c. Showcase Portfolio}

This type of portfolio is best used for summative evaluation of students' mastery of the core curriculum learning outcomes. This portfolio includes the best work of students who are determined by both teachers and students

\section{Research Methods}

This type of research is a development research (Research and Development), using the ADDIE development model through 5 stages, namely: analyze, design, development, implementation and evaluation. Research and development is a research method used to produce certain products and test the effectiveness of these products. The product developed and tested for its effectiveness in this study is a computer-based portfolio assessment. The subjects in this study consisted of 3 teachers in Group A TK ABA 05 Medan. Then 6 validation experts who have the appropriate knowledge of this development research, among others: a) 2 assessment experts, b) 2 computer experts, c) 2 early childhood experts. The determination of the feasibility level of the portfolio assessment instrument is based on the validation test of the experts, while the level of effectiveness of the portfolio assessment instrument is based on trials with the teacher through the teacher response questionnaire using the gain score.

\section{Discussion}

The results of research on the development of a computer-based assessment of the creativity portfolio assessment instrument for kindergarten children include eligibility and effectiveness criteria. Data collection was carried out using expert validation questionnaire sheets and teacher response questionnaire sheets. Data collection was carried out at TK ABA 05 Medan in March 2020 with the theme My Country.

The steps taken to obtain a portfolio assessment instrument in this study are the ADDIE development model. The ADDIE model steps include aspects of analyze, design, development, implementation and evaluation.

The feasibility of a portfolio assessment describes: (1) feasibility of assessment, (2) feasibility of computers, (3) eligibility of early childhood. The feasibility of the portfolio assessment is obtained after going through an expert validation process. 
The three validations of experts who have provided input and provided an assessment of the developed portfolio, the following is a comparison of the percentage of each expert validation.

Data obtained from experts in the form of qualitative data was conventionally scored quantitative data; the scoring was adjusted to the likert scale. To determine the feasibility of portfolio assessment, the validity test was carried out by assessment experts, computer experts and early childhood experts. Each expert provides an assessment of each indicator contained in the questionnaire. The product deserves to be tested in the field if every expert has validated the product with a valid category with revision or without revision.

From the results of the average percentage of the six validation experts stated that the product of the computer-based kindergarten children's creativity portfolio assessment instrument was categorized as very valid or very feasible with an average score of $83 \%$. So that from the feasibility test, the computer-based kindergarten children's creativity portfolio assessment instrument is feasible to use.

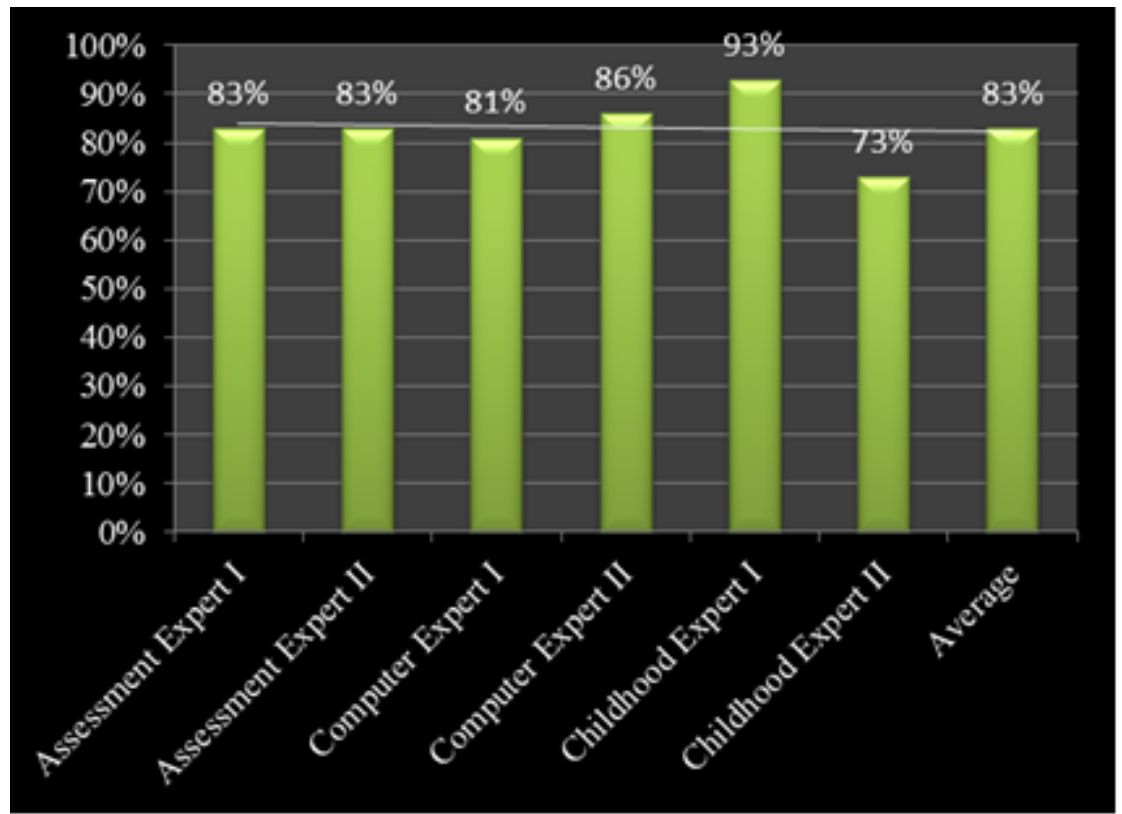

Figure 1. Diagram of the Recapitulation of Portfolio Assessment Validation Results

Based on the six expert validations (assessment, computer and early childhood), there is a difference in the assessment. The highest assessment was found in early childhood experts I with a percentage of $93 \%$ and categorized as very feasible, while the lowest assessment for early childhood experts II was $73 \%$ and categorized as valid, while the average percentage score of the six experts reached a score of $83 \%$ with very category. valid and very feasible.

Portfolio assessment is categorized as effective if the teacher can understand and use the portfolio assessment instrument as expected. The effectiveness of the portfolio assessment can be seen from the gain score taken from the pre-test and post- test activities of the teacher in conducting the assessment contained in the teacher response questionnaire. From the results of the teacher's questionnaire responses before and after using portfolio assessment in the six assessment activities, the average pretest score was 13.3 and the posttest score was 21.3. Then it is calculated using the gain score formula and obtaining a value of 0.74 . The assessment instrument for the creativity portfolio of computer-based kindergarten children is categorized as having high effectiveness.

The effectiveness of the portfolio assessment between before and after using a computer-based assessment instrument of the creativity portfolio of kindergarten children is 
calculated using a normalized gain score formula. Gain score is a good indicator to show the level of treatment effectiveness from the posttest score acquisition.

Table 1. Gain Score Test Results

\begin{tabular}{|c|c|c|c|}
\hline & & Statistic & Std. Error \\
\hline Uji_Gain_Score & $\begin{array}{l}\text { Mean } \\
\text { 95\% Confidence Interval Lower Bound } \\
\text { for Mean Upper Bound } \\
5 \% \text { Trimmed Mean } \\
\text { Median } \\
\text { Variance } \\
\text { Std. Deviation } \\
\text { Minimum } \\
\text { Maximum } \\
\text { Range } \\
\text { Interquartile Range } \\
\text { Skewness } \\
\text { Kurtosis }\end{array}$ & $\begin{array}{l}.7444 \\
.4310 \\
1.0579 \\
.8000 \\
.016 \\
.12620 \\
.60 \\
.83 \\
.23 \\
\\
-1.597\end{array}$ & 1.225 \\
\hline
\end{tabular}

Based on the data above, the gain score reaches 0.74 . It can be categorized that the computer-based assessment instrument for the creativity portfolio of kindergarten children has high effectiveness.

There are many advantages and advantages obtained from using a portfolio appraisal application in the appraisal process. Portfolio appraisal applications have the potential to adapt and can be effectively used to facilitate the assessment process, impacting teacher performance even further. This application can help teachers to assess children's creativity; teachers can make an assessment rubric of each child's activity which will help teachers to assess the extent to which children's creativity is developing which can then be reported to parents at any time in softcopy via social media, no need to wait for one. Semester in stofmap form

However, this application also has drawbacks, one of which is that the teacher must use a computer that matches the version of the assessment application, if the computer is too low or too high the application cannot be used. Then the teacher who uses this assessment application must understand and understand accessing computers.

\section{Conclusion}

The result of this research is a computer-based assessment instrument product of the creativity portfolio of kindergarten children. This product is feasible and valid for use at TK ABA 05 Medan through assessment, revision and validation from several experts. This conclusion is drawn based on the results of the analysis of experts consisting of assessment experts $\mathrm{I}$ in this category are considered very valid with a percentage of $83 \%$ which means very suitable for use and assessment experts II in the category considered very valid with a percentage of $83 \%$ which means very suitable for use. Then the computer expert $I$ in the category is considered valid with a percentage of $81 \%$ which means that it is suitable for use and the computer expert II in the category is considered very valid with a percentage of $86 \%$ which means very suitable for use. 
Furthermore, early childhood expert I in the very valid category with a percentage of $93 \%$ which means that it is very suitable for use and early childhood expert II in the category is considered valid with a percentage of $73 \%$ which means it is suitable for use.

The pretest results of the teacher response questionnaire before using the application reached an average of 13.3, while the posttest teacher response questionnaire after using the application reached 21.3. To see the effectiveness of the portfolio assessment using the gain score test with a value of 0.74 and can be categorized as high effectiveness.

\section{References}

Abdillah, Syaukani, and Sitorus, Y. 2020. The Ability of Latin Letter Recognition in Early Children in Raudhatul Atfhal Annajamissa'adah Medan Tembung. Budapest International Research and Critics Institute-Journal (BIRCI-Journal) (3): 791-798.

Ambara, Didith Pramunditya \& dkk. 2014. Asesmen Anak Usia Dini. Yogyakarta : Graha Ilmu.

Amelia, L., Hayati, F., Milfayetti, S., and Ichsan. 2019. Analysis of the Use of Kindergarten Watching Siaga Bencana Learning Model for Structured Positive Thinking Ability on Early Childhood. Budapest International Research and Critics Institute-Journal (BIRCIJournal) (2): 379-387.

Arifah, Fatih \& Yustisianisa. 2012. Evaluasi Pembelajaran. Jakarta : Mentari Pustaka.

Bambang Harmanto \& Dian Kristiana. 2018. Memudahkan Pelaporan Perkembangan Anak TK Melalui Program Aplikasi. Jurnal AUDI. Vol. II No. 2 Hal. 103-110.

Deliati, Dewi, R. S., and Lesmana, G. 2019. Spirografh Media for Kindergarten Teachers of 'Aisyiyah in Tanjung Sari Village. Budapest International Research and Critics in Linguistics and Education (BirLE) (2): 468-471.

Komang Setemen, Luh Joni Erawati Dewi \& I Ketut Purnamawan. 2019. Model Peer Assesment Berbasis Teknologi Informasi dan Komunikasi. Jurnal Pendidikan Teknologi dan Kejuruan Vol. 16 No. 1 Hal. 55-64.

Mutiah, Diana. 2010. Psikologi Bermain Anak Usia Dini. Jakarta : Kencana.

Rachmawati, Y \& Kurniati E. 2010. Srategi Pengembangan Kreativitas Pada Anak Taman Kanak-Kanak. Jakarta : Kencana.

Rafida, T., Harahap, M. 2020. Implementation of Playing Methods in Learning Science in Improving Children's Critical Thinking Ability in Raudhatul Athfal Assyifa Medan. Budapest International Research and Critics Institute-Journal (BIRCI-Journal) (3): 868875.

Saragi, Daulat. 2014. Konstruktivisme Jean Piaget dalam Teori Bermain, Suatu Pembelajaran Seni Pada Anak. Fakultas Bahasa dan Seni Universitas Negeri Medan.

Sujiono, Yuliani Nuraini. 2010. Mengajar dengan Portofolio. Jakarta : Indeks.

Surapranata, Sumarna \& Hatta, M. 2007. Penialain Portofolio Implementasi Kurikulum 2004. Bandung : Remaja Rosdakarya.

Susanto, Ahmad. 2011. Perkembangan Anak Usia Dini Pengantar dalam BerbagaiAspeknya. Jakarta : Kencana. 